ATTHULAB:

Islamic Religion Teaching $\mathcal{E}$ Learning Journal

Volume 4 Nomor 2 Tahun 2019

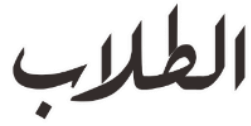

http://journal.uinsgd.ac.id./index.php/atthulab/

\title{
Disposisi asesmen mahasiswa calon guru Pendidikan Agama Islam
}

\section{Ujang Dedih'), Maslani2), Hamdan Sugilar ${ }^{3)}$ dan Dadan F. Ramdhan ${ }^{4)}$}

\author{
1)Jurusan Pendidikan Agama Islam \\ Universitas Islam Negeri Sunan Gunung Djati Bandung \\ Jalan Soekarno Hatta Kota Bandung Jawa Barat 40629 Indonesia \\ Email: ujangdedih@uinsgd.ac.id \\ 2)Jurusan Pendidikan Agama Islam \\ Universitas Islam Negeri Sunan Gunung Djati Bandung \\ Email: maslani@uinsgd.ac.id \\ 3) Prodi Pendidikan Matematika \\ Universitas Islam Negeri Sunan Gunung Djati Bandung \\ Email: hamdansugilar@uinsgd.ac.id \\ 4) Jurusan Pendidikan Bahasa Arab \\ Universitas Islam Negeri Sunan Gunung Djati Bandung \\ Email: dadanramdhan74@uinsgd.ac.id
}

\begin{abstract}
Learning achievement is a competency ability possessed by graduates after completing a study program, to measure learning achievement there is a need for a comprehensive and focused instrument measuring professional readiness and personality of students as prospective Islamic education teachers (PAI). This research method is a descriptive study in the form of a case study. The object in this study were students of PAI majoring in Tarbiyah and Teacher Training at one of the universities in the city of Bandung from various levels (level IV, VI, and VIII) of PAI lecturers, the instruments used consisted of questionnaires, interviews and literature studies. The purpose of this study was to determine the readiness of students to become PAI teachers, evaluate the curriculum that has been implemented so that it is expected that prospective teacher students are ready to become teachers. Of course, this is an irony that students do not love their identity as students of educational institutions and education workers who do not like their profession. Based on the results of the research the level of confidence of PAI teacher candidates to be teachers is in the range of 2.95 or in the high category; PAI student learning motivation is $2.42 \%$ in the medium category. With more than $50 \%$ of students having a positive attitude and enthusiasm for learning; the average student response to PAI learning activities is 1.64 in the medium category and $75 \%$ of students answer questions from the lecturer and show regular attendance.
\end{abstract}

Keywords:

assesment; disposition

\begin{abstract}
Abstrak: Prestasi belajar adalah kemampuan kompetensi yang dimiliki oleh lulusan setelah menyelesaikan program studi, untuk mengukur prestasi belajar ada kebutuhan untuk instrumen yang komprehensif dan fokus mengukur kesiapan profesional dan kepribadian siswa sebagai calon guru pendidikan Islam (PAI). Metode penelitian ini adalah penelitian deskriptif dalam bentuk studi kasus. Objek dalam penelitian ini adalah mahasiswa PAI jurusan Tarbiyah dan Pelatihan Guru di salah satu universitas di kota Bandung dari berbagai tingkatan (level IV, VI, dan VIII) dosen PAI, instrumen yang digunakan terdiri dari angket, wawancara dan studi literatur. Tujuan dari penelitian ini adalah untuk mengetahui kesiapan siswa untuk menjadi guru PAI, mengevaluasi kurikulum yang telah diterapkan sehingga diharapkan calon guru siswa siap menjadi guru. Tentu saja, ini adalah ironi bahwa siswa tidak mencintai identitas mereka sebagai siswa dari lembaga pendidikan dan pekerja pendidikan yang tidak menyukai profesi mereka. Berdasarkan hasil penelitian tingkat kepercayaan calon guru PAI untuk menjadi guru berada
\end{abstract}


pada kisaran 2,95 atau dalam kategori tinggi; Motivasi belajar siswa PAI adalah 2,42\% dalam kategori sedang. Dengan lebih dari 50\% siswa memiliki sikap positif dan antusiasme untuk belajar; rata-rata respons siswa terhadap kegiatan pembelajaran PAI adalah 1,64 dalam kategori sedang dan $75 \%$ siswa menjawab pertanyaan dari dosen dan menunjukkan kehadiran teratur.

Kata kunci:

asesmen; disposisi

DOI: http://dx.doi.org/10.15575/ath.v4i2.6228

Received: 10, 2019. Accepted: 11, 2019. Published: 11, 2019

\section{PENDAHULUAN}

Peningkatan profesionalitas guru telah banyak dilakukan. Namun dalam implementasinya, masih mengalami berbagai hambatan. Hal itu disebabkan karena lemahnya pemahaman guru memaknai profesionalisme, ditambah kuatnya hegemoni kepentingan politik dan kekuasaan, baik di lingkungan Kemendikbud maupun di lingkungan Dinas Pendidikan Provinsi dan Kabupaten/Kota. Padahal, upaya apapun yang dilakukan untuk meningkatkan kualitas pendidikan, tidak akan memberikan kontribusi signifikan, jika tidak didukung oleh guru profesional dan berkualitas. Hal ini akan berimplikasi pada standar yang dimiliki para guru secara nasional belum sesuai harapan Kondisi yang memprihatinkan tersebut, terbukti berdasarkan laporan yang mengejutkan dari Kementerian Pendidikan dan Kebudayaan bahwa hasil nilai rata-rata Uji Kompetensi Guru (UKG) pada tahun 2013 di seluruh Indonesia hanya 4,25. Bahkan Menteri Pendidikan dan Kebudayaan mengaku kecewa melihat hasil UKG yang menunjukkan nilai guru di 316 kabupaten/kota di bawah rata-rata. UKG yang dilakukan baik secara online dan offline, merupakan alat untuk mengukur kompetensi para guru, dengan materi yang diujikan meliputi $30 \%$ aspek kompetensi pedagogik dan $70 \%$ kompetensi professional. Data tersebut menjadi fakta bahwa guru atau calon guru harus diberikan pemahaman terhadap pentingnya peningkatan kompetensi guru mengingat guru berperan strategis dalam meningkatkan kualitas dan mutu pendidikan ((LPMP), 2011:34).

Kompetensi guru perlu disiapkan sejak menjadi mahasiswa melalui pengembangan kegiatan akademik dan akademik agar mereka memahami dan mengetahui tugas pokok guru, salah satu upaya untuk mengukur kesiapan tersebut melalui asesmen. Asesmen merupakan bagian yang penting pada pembelajaran. Salah satu jenis asesmen yang penting dilaksanakan adalah assesment for learning, atau sering disebut sebagai asesmen formatif, Peran yang pertama adalah memberi acuan pendidik dalam mengambil keputusan selama proses pembelajaran melalui informasi dari peserta didik. Peranan yang kedua berkaitan langsung dengan peserta didik yaitu memberi feedback kepada peserta didik untuk memperbaiki proses belajarnya (Sugilar, 2017:2). Assessment bagian yang tidak dapat dipisahkan dari setiap kegiatan fungsi dan peranannya tergantung dari tujuan yang hendak dicapai. Melalui Asesmen mahasiswa dapat mengukur capaian belajarnya, mengetahui ketetapan metode pembelajaran dan ketetapatan kurikulum yang dilaksanakan. Upaya dalam melaksanakan Asesmen yang baik sering kali dilakukan mengingat ketepatan Asesmen dalam hal mengukur tingkat kevalidan instrument, ketepatan waktu dan jenis soal dan menganalisa setiap butir soal, sehingga tidak terjadi miss antara tujuan dengan instrument yang diberikan.

Tantangan guru Pendidikan Agama Islam (PAI) di masa depan sangat besar dan berat (Nasir, 2013:201), dibutuhkan kesiapan kompetensi yang mumpuni dalam menyiapkan pembelajaran yang professional siap lahir dan batin menjadi guru. Capaian 
pembelajaran merupakan kemampuan kompetensi yang dimiliki lulusan setelah menyelesaikan suatu program studi. Karena itu, capaian pembelajaran sangat terkait dengan profil lulusan. Setelah dilakukan studi pada tracer study kepada pengguna potensial yang sesuai dengan bidang studi dan setelah melakukan identifikasi peran lulusan Jurusan PAI bahwa profil Jurusan PAI ditetapkan profil Jurusan PAI sebagai Pendidik Pendidikan Agama Islam (PAI) pada lembaga sekolah/madrasah dan luar sekolah yang memiliki kemampuan profesional, berdaya saing serta mampu merespon perkembangan zaman. Mahasiswa sebagai calon guru pendidikan Agama Islam harus mengetahui dan menguasai tentang berbagai aspek dalam persiapan menjadi guru, salah satu aspeknya adalah motivasi dan pedagogik yang pada kenyataan ini dalam kategori sedang perlu utuk ditingkatkan (Suhadi dkk, 2014:60). Kinerja dan kompetensi seorang guru telah menjadi poin penting untuk didiskusikan karena fakta itu dapat menjadi aspek hukum dalam merancang dan mengembangkan kinerja dan kompetensi guru. Kinerja adalah sejauh mana guru telah mencapai dalam hal tanggung jawab kerja, dengan kata lain, prestasi kerja guru. Oleh karena itu, guru dengan kinerja tinggi adalah mereka yang menguasai materi pengajaran dan metode pengajaran (Ismail, 2010: 44).

Mahasiswa harus siap menjadi guru yang professional tidak terpaksa dan tidak dipaksa untuk menjadi guru, sehingga melalui jurusan pendidikan Agama Islam ini terlahir calon guru yang professional dengan personality yang baik. Diperlukan langkah yang tepat untuk mengetahui kesiapan siswa menjadi guru, sehingga tidak diharapkan mahasiswa calon guru tidak siap untuk menjadi guru. Lembaga perlu menyiapkan calon guru agar mereka siap dalam menjalankan peran dan fungsinya, melalui disposisi assessment ingin diketahui nilai-nilai kejujuran, empati, tanggung jawab, dan berpikirnya. Tentu ini menjadi ironi mahasiswa tidak mencintai identitas dirinya sebagai mahasiswa lembaga pendidik dan tenaga pendidikan yang tidak menyenangi profesinya. Untuk menjawab permasalahan tersebut diperlukan tools untuk mengetahui kesiapan mahasiswa untuk menjadi guru, aspek-aspek yang perlu ditingkatkan dan mengetahui dan meningkatkan mental mereka untuk siap menjadi guru karena menjadi guru professional itu perlu dipersiapkan.

Kompetensi kepribadian yang menjadi perhatian bagi guru dalam pembelajaran di kelas adalah percaya diri guru atau teachers' belief tingkat keyakinan guru dapat ditingkatkan melalui beberapa cara. Kontribusi kompetensi guru untuk motivasi berprestasi adalah sebesar 11,3\% dan 88,7\% dipengaruhi oleh faktor lain (Irawan, 2010:65), ini menunjukkan bahwa guru yang kompeten dalam memimbing siswa akan mempengaruhi hasil belajar siswa Fokus pada penelitian ini adalah mengetahui mengembangkan instrument untuk mengukur kesiapan mahasiswa jurusan pendidikan Agama Islam untuk menjadi guru, aspek yang perlu ditingkatkan untuk menjadi guru dan mengukur kesiapan mental calon guru untuk menjadi guru. Kajian yang dilakukan adalah dengan memberikan instrument berupa angket yang telah disusun melalui analisis tes yang diuji oleh para ahli, wawancara dan seminar hasil dari temuan di lapangan. Sehingga mahasiswa memiliki mental yang siap dan percaya diri untuk menjadi guru.

\section{METODE PENELITIAN}

Jenis penelitian ini merupakan penelitian deskriptif berbentuk studi kasus mengenai mengukur kesiapan calon guru PAI menjadi guru tentang tingkat kepercayaan diri atau belief teaching, sikap dan penguasaan materi. Objek dalam penelitian ini adalah mahasiswa jurusan PAI salah satu perguruan tinggi di kota Bandung dari berbagai tingkatan ( tingkat IV, VI, dan VIII), dosen dan Kajur PAI. Instrumen penelitian terdiri 
dari angket, pedoman wawancara, dan pedoman observasi. Data penelitian ini dianalisis secara deskriptif untuk mendeskripsikan keyakinan guru dalam pembelajaran matematika dan faktor-faktor yang mempengaruhinya. Adapun tabel konversi tentang tingkat kepercayaan diri guru disajikan pada tabel berikut:

Tabel 1. Konversi Tentang Tingkat Kepercayaan Diri Guru

\begin{tabular}{ccl}
\hline No. & Rata-rata Teacher Belief & \multicolumn{1}{c}{ Keterangan } \\
\hline 1. & $0 \leq$ rerata $<1,3$ & Rendah \\
2. & $1,3 \leq$ rerata $<2,6$ & Sedang \\
3. & $2,6 \leq$ rerata $\leq 4$ & Tinggi \\
\hline
\end{tabular}

\section{HASIL PENELITIAN DAN PEMBAHASAN}

\section{A. Kompetensi Professional}

Menjadi guru professional merupakan sebuah harapan dan cita-cita semua pendidik. Kata Professional harus melekat pada semua guru, mengingat guru yang professional dapat mempengaruhi kualitas pendidikan. Untuk membangun dan membentuk guru yang professional dibutuhkan regulasi dan strategi, mengingat menjadi guru yang professional tidak dapat dibentuk secara instan tetapi kontinu baik niat dari guru tersebut maupun upaya pemerintah untuk membentuk guru professional. Profesional adalah pekerjaan atau kegiatan yang dilakukan oleh seseorang dan menjadi sumber penghasilan kehidupan yang memerlukan keahlian, kemahiran, atau kecakapan yang memenuhi standar mutu atau norma tertentu serta memerlukan pendidikan profesi. UU No. 14 Tahun 2005 tentang Guru dan Dosen menjabarkan bahwa kompetensi profesional adalah kemampuan penguasaan materi pelajaran secara luas dan mendalam. Menguasai materi atau substansi materi merupakan hal yang mutlak dikuasai oleh setiap guru. Kemampuan untuk menguasai materi pelajaran tidak hanya sebatas menguasai substansinya saja tetapi menguasai komponen dan filosofi dari materi tersebut mampu mengembangkan dan menjabarkan materi secara luas dan benar. Untuk itu, kompetensi profesional meliputi kepakaran atau keahlian dan berdedikasi yang tinggi.

Undang-Undang No. 14 tentang Guru dan Dosen (2005) bahwa kompetensi adalah seperangkat pengetahuan, keterampilan, dan perilaku yang harus dimiliki, dihayati, dan dikuasai oleh guru atau dosen dalam melaksanakan tugas keprofesionalnya. dinyatakan bahwa seorang guru yang profesional harus memiliki empat kompetensi pendidik, yaitu kompetensi pedagogik, kepribadian, sosial, dan profesional. Ada dua hal yang tidak bisa ditawar-tawar lagi untuk menjadi guru yaitu kemampuan menguasai materi pelajaran dan keterampilan mengajar di samping ada keterampilan lain yang perlu dimiliki juga misalnya keterampilan berkomunikasi, kepribadian dan sosial. Keterampilan mengajar merupakan kompetensi kompetensi profesional guru yang cukup kompleks. Keterampilan tersebut merupakan keterampilan wajib yang harus dikuasai oleh guru, tanpa menguasai keterampilan mengajar sulit untuk mencapai tujuan pembelajaran dengan baik, karena merupakan integrasi dari berbagai kompetensi guru secara utuh dan menyeluruh, bagaimana mungkin materi akan tersampaikan dengan baik manakala guru tidak menguasai keterampilan menyampaikan materi dengan tepat kepada siswanya, materi sampai ke siswa namun apakah dapat diterima oleh siswa. Ini yang menjadi perhatian guru, catatan siswa yang banyak belum mengindikasikan bahwa mereka mengerti dan memahami. Kompetensi 
merupakan perilaku rasional guna mencapai tujuan yang dipersyaratkan sesuai dengan kondisi yang diharapkan (Sanjaya, 2006:17). Menurut Syaiful Sagala (2011:29) kompetensi adalah kemampuan melaksanakan sesuatu yang diperoleh melalui pendidikan dan latihan

Ada delapan keterampilan mengajar yang berperan terhadap kualitas pembelajaran, yaitu (1) keterampilan bertanya, (2) mengadakan penguatan, (3) mengadakan variasi, (4) kemampuan menjelaskan, (5) membuka dan menutup pelajaran, (6) membimbing diskusi kelompok kecil, (7) mengelola kelas, (8) mengajar kelompok kecil dan perorangan. Keterampilan mengajar itu harus dikuasai secara utuh dan terintegrasi, sehingga diperlukan latihan yang sitematis melalui micro teaching atau pembelajar mikro atau pengajaran mikro (Mulyasa, 2005: 69-92).

\section{B. Kompetensi Kepribadian}

Kepribadian berkaitan dengan pribadi yang memiliki sikap yang memiliki integritas yang baik untuk dirinya atau menjadi teladan bagi yang lainnya. Secara rinci kompetensi kepribadian guru dapat di gambarkan sebagai berikut: mantap, stabil, dan dewasa. Pribadi mantap berarti memiliki suatu kepribadian yang tidak tergoyahkan agar dapat melaksanakan tugasnya dengan baik, profesional dan bertanggung jawab. Arif dapat berarti bijaksana; cerdik; pandai; berilmu; mengetahui. Memiliki kepribadian arif, yang di tunjukkan dengan tindakan yang bermanfaat bagi peserta didik, sekolah dan masyarakat serta menunjukkan keterbukaan dalam berfikir dan bertindak. Guru bukan hanya menjadi seorang manusia pembelajar tetapi menjadi pribadi bijak, seorang saleh yang dapat mempengaruhi pikiran generasi muda. Guru merupakan teladan bagi para peserta didik dan semua orang yang beranggapan dia sebagai guru. Pribadi guru sangat berperan dalam membentuk pribadi peserta didik. Ini dapat dimaklumi karena manusia merupakan makhluk yang suka mencontoh, termasuk mencontoh pribadi gurunya dalam membentuk pribadinya. Secara teoritis, menjadi teladan merupakan bagian integral dari seorang guru, sehingga menjadi guru berarti menerima tanggung jawab menjadi teladan.

\section{Disposisi Asesmen}

Disposisi adalah keinginan, kesadaran, kecenderungan dan dedikasi yang kuat pada diri mahasiswa untuk berpikir dan berbuat yang menunjukkan rasa percaya diri, ekspektasi dan metakognisi, gairah dan perhatian serius dalam belajar, kegigihan dalam menghadapi dan menyelesaikan masalah, rasa ingin tahu yang tinggi, serta kemampuan berbagi pendapat dengan orang lain. Hasil penelitian mengungkapkan terdapat korelasi yang signifikan antara sikap kepercayaan diri dan kinerja. Akibatnya, tampak bahwa mahasiswa dengan sikap positif yang baik dan memiliki kepercayaan diri tinggi pada domain yang spesifik akan lebih baik dalam pemecahan masalah (Philippou, 2004: 1). Disposisi assesement berarti Asesmen untuk mengetahui sikap dan rasa percaya diri yang tinggi terhadap kompetensi yang dimiliki.

Menurut Carr (2001) disposisi pembelajaran sebagai strategi pembelajaran yang ada plus motivasi-partisipasi repertoar dari mana pelajar mengenali, memilih, mengedit, merespon untuk, menolak, mencari dan membangun kesempatan belajar Penilaian disposisi di kelas dan lapangan memberikan pendidik kepada calon guru dengan profil yang lebih holistik yang diberikan. Sangat penting bahwa proses penilaian aspek pengajaran yang penting semacam itu dilakukan dengan hati-hati dan terampil. Perawatan akan membantu memastikan penilaian yang lebih valid dan dapat diandalkan disposisi siswa di lapangan. Hasil penelitian untuk mengukur tingkat 
keyakinan guru matematika dalam mengajar diperoleh data sebagai berikut: keyakinan guru dalam pembelajaran tergolong sedang (rerata 2,54 dengan skala 4), faktor-faktor yang mempengaruhinya diantaranya: keyakinan guru berpendidikan S2 lebih baik daripada berpendidikan S1/D3, keyakinan guru dari sekolah negeri lebih tinggi daripada sekolah swasta, keyakinan guru mengalami peningkatan secara bertahap mulai 0 sampai 20 tahun, dan mengalami penurunan setelah 20 tahun (Sutiarso, 2017:10). Pada penelitian ini aspek yang diamati adalah keyakinan calon guru PAI untuk menjadi guru PAI. Adapun hasil angket sebagai berikut:

Tingkat kepercayaan calon guru PAI berdasarkan kebanggaan menjadi mahasiswa PAI. Kepercayaan ini merupakan bagian yang tidak terpisahkan dari semangat atau implementasi dari sikap seseorang yang meyakini dirinya mampu melakukan atau berbuat sesuatu dengan sadar dan yakin. Sifat orang yang memiliki tingkat kepercayaan yang tinggi akan dengan sadar dan yakin mampu berbuat dengan baik dan maksimal, memiliki semangat dari dalam diri merupakan hal penting yang menjadi spirit bahwa dirinya sebagai pribadi yang kuat, tangguh dan mampu melakukan kegiatan dengan hasil maksimal. Tentunya kepercayaan diri yang dilakukan tidak membuat dirinya lebih dari orang lain tetapi dapat bermanfaat bagi orang lain. Tingkat kepercayaan diri mahasiswa merupakan bekal awal sebagai spirit dari dalam dirinya untuk mau dan siap menjadi pribadi yang mantap, berani dan memiliki semangat yang tinggi terhadap pekerjaan yang dihadapi. Orang yang percaya diri yang dibarengi dengan attitude dan kompetensi akademik yang baik akan membawa dirinya kedalam lingkungan yang mendorong untuk berbuat yang baik agar bermanfaat bagi dirinya dan orang lain.

Tabel 2. Tingkat kepercayaan calon guru PAI

\begin{tabular}{clcc}
\hline No & \multicolumn{1}{c}{ Pernyataan } & Jumlah & Ya (\%) \\
\hline 1. & Kuliah di Jurusan PAI adalah pilihan saya & 43 & 60 \\
2. & Saya bangga kuliah di Jurusan PAI & 46 & 64 \\
3. & Saya bercita-cita ingin menjadi guru PAI & 43 & 60 \\
4. & Saya ingin menjadi guru PAI yang Profesional & 46 & 64 \\
5. & Saya kurang percaya diri untuk menjadi guru PAI & 35 & 48 \\
& rata-rata $=\frac{\text { Jumlah }}{72}$ & 2,95 & $59,2 \%$ \\
\hline
\end{tabular}

Pada tabel 2. diperoleh bahwa $60 \%$ menyatakan bahwa kuliah pada jurusan PAI merupakan pilihan pertama sehingga kita dapat asumsikan bahwa data tersebut menunjukkan kesiapan menjadi guru dan hal ini diperkuat pula dengan data bahwa 60 $\%$ mahasiswa/i bercita-cita ingin menjadi guru. Rata-rata tingkat kepercayaan calon guru PAI menjadi guru berada pada rentang 2,95 atau pada kategori tinggi. Ini menunjukkan bahwa calon guru PAI siap untuk menjadi guru PAI. Data tersebut merupakan informasi tentang apakah calon guru atau mahasiswa PAI benar-benar ingin mengabdikan menjadi guru atau sebaliknya, namun dari data tersebut menunjukkan kesiapan mereka memilih jurusan PAI untuk menjadi guru. Untuk lebih menggali informasi perihal upaya apa yang dilakukan untuk mempersiapkan menjadi guru salah satunya disajikan pada tabel 3 . berikut: 
Tabel 3. Motivasi Belajar Calon Guru PAI

\begin{tabular}{llcc}
\hline No & \multicolumn{1}{c}{ Pernyataan } & Jumlah & Ya (\%) \\
\hline $\begin{array}{l}\text { 1. } \\
\text { 2. }\end{array} \quad$ Saya tetap belajar ada atau tidak ada tugas kuliah & 34 & 46 \\
3. $\quad \begin{array}{l}\text { Tugas kuliah saya kerjakan dengan sungguh- } \\
\text { sungguh dan tepat waktu }\end{array}$ & 44 & 51 \\
4. $\quad \begin{array}{l}\text { Sebelum kuliah dimulai saya membaca materi } \\
\text { terlebih dahulu }\end{array}$ & 23 & 32 \\
5. $\quad$ Nilai-nilai mata kuliah sangat membanggakan & 36 & 50 \\
$\quad$ rata-rata $=\frac{\text { Jumlah }}{72}$ & 2,42 & 48 \\
\hline
\end{tabular}

Pada tabel 3. diperoleh gambaran bahwa rata-rata motivasi belajar mahasiswa PAI sebesar 2,42 berada pada kategori sedang. Data tersebut menunjukkan bahwa secara keseluruhan mahasiswa memiliki motivasi belajar yang tinggi, tetapi pada aspek mahasiswa membaca materi terlebih dahulu sebelum kuliah hanya $23 \%$ mahasiswa yang melakukan kegiatan tersebut dan tetap belajar walau tidak ada atau tidak ada tugas kuliah sebesar prosentase $34 \%$ atau kurang dari setengahnya. Sehingga dua indikator tersebut berada pada kategori rendah.

Tabel 4. Aktivitas Pembelajaran

\begin{tabular}{llll}
\hline No & \multicolumn{1}{c}{ Pernyataan } & Ya & $(\%)$ \\
\hline 1. & $\begin{array}{l}\text { Saya memperhatikan dosen menyampaikan materi } \\
\text { dengan baik }\end{array}$ & 42 & 58 \\
2. & $\begin{array}{l}\text { Mata kuliah yang dipelajari cukup sebagai bekal untuk } \\
\text { menjadi guru }\end{array}$ & 26 & 37 \\
3. & $\begin{array}{l}\text { Dosen di jurusan PAI sangat profesional } \\
\text { 4. }\end{array}$ & 32 & 44 \\
5. & $\begin{array}{l}\text { Setelah lulus kuliah, saya tidak akan menjadi guru } \\
\text { perkuliahan menemukan kendala dalam menghadapi }\end{array}$ & 66 & 91 \\
& Rata-rata & 12 & 17 \\
\end{tabular}

Pada tabel 4. diperoleh gambaran bahwa rata-rata respon mahasiswa terhadap aktivitas pembelajaran PAI sebesar 1,64 berada pada kategori sedang. Data tersebut menunjukkan bahwa aktivitas mahasiswa dalam belajar berada pada kategori sedang secara keseluruhan dan 91 \% mahasiswa ingin menjadi guru PAI. Ada 17 \% mahasiswa mengalami kesulitan dalam menghadapi perkuliahan salah satunya karena kemampuan bahasa arab yang kurang. Berdasarkan hasil wawancara tentang harapan mahasiswa terhadap mata kuliah yang diterima/diberikan oleh jurusan PAI yang dilakukan kepada mahasiswa PAI sebagai berikut: materi yang disampaikan harus lebih refresentatif dan komprehensif; materi yang diberikan up date tidak monoton dan berbasis IT juga; diselenggarakan pesantren sebelum wisuda diselenggarakan, khususnya pendalaman materi ke PAI an dan dosen dapat menjadi teladan bagi mahasiswanya. Pertanyaan yang kedua jika saudara merasa tidak percaya diri untuk menjadi guru PAI kemukakan alasannya diperoleh kesimpulan sebagai berikut: saya merasa kurang percaya diri karena calon guru dan sarjana PAI yang banyak menjadikan saya harus bersaing ketat terutama dengan alumni dari pesantren. Beberapa mata kuliah yang saya merasa kurang 
memahaminya diantaranya: tarikh Islam, Qiroatul Qutub, bahasa Arab, Qur'an dan Hadits. Tabel 5 dan 6 menunjukkan profesionalisme dan sikap antusiasme calon guru PAI. Angket disebarkan kepada mahasiswa yang mengampu mata kuliah microteaching yang dilakukan oleh delapan dosen PAI dengan subjek sampel masing-masing tiga mahasiswa di peroleh data sebagai berikut:

Tabel 5. Menunjukkan Profesionalisme

\begin{tabular}{llcc}
\hline No & \multicolumn{1}{c}{ Pernyataan } & \multicolumn{2}{c}{ Kategori (\%) } \\
& & Ya & Tidak \\
\hline 1. & Menjawab pertanyaan saat ditanya Dosen & 75 & 25 \\
2. & Menunjukkan kehadiran secara teratur & 75 & 25 \\
3. & Terampil membuat perencanaan pembelajaran & 38 & 63 \\
4. & Penampilan yang professional ketika menyampaikan materi/ & 50 & 50 \\
& pelaksanaan pembelajaran & 63 & 38 \\
5. & Terampil melaksankan pembelajaran & 63 & 50 \\
6. & Mendengarkan dengan tenang sementara yang lain sedang & 50 & 58 \\
& berbicara & \multicolumn{2}{c}{63} \\
7. & Terampil dalam menggunakain IT dalam pembelajaran & \multicolumn{2}{c}{} \\
\hline
\end{tabular}

Tabel 5. tentang menunjukkan profesionalisme sebagai mahasiswa calon guru PAI. Jurusan PAI berusaha mewujudkan calon guru PAI yang profesional tentunya perlu dibangun mekanisme yang tepat untuk mewujudkannya salah satunya adalah menyusun program kerja jurusan yang tepat dan selaras dengan visi misi yang ingin diwujudkan. dibangun sejak mahasiswa. $75 \%$ mahasiswa menjawab pertanyaan dari dosen dan menunjukkan kehadiran yang teratur. Hal perlu untuk ditingkatkan adalah keterampilan mahasiswa dalam menyusun rencana pembelajaran dan menggunakan IT dalam pembelajaran hal ini dapat dilihat pada tabel sebanyak $38 \%$ yang mampu membuat. Untuk itu perlu kiranya kedua aspek membuat RPP dan penggunaan IT ditingkatkan dan menjadi poin penting untuk diperbaiki dan di evaluasi sehingga solusi yang tepat terhadap kelemahan ini teratasi dengan baik. Salah satu upaya untuk meningkatkan profesionalisme calon guru PAI yaitu: memiliki dosen professional di bidangnya; memberikan materi perkuliahan tidak semata- mata yang bersifat teoritis tetapi diimbangi dengan perkuliahan yang bersifat praktis; memberikan pelatihan dan keterampilan kepada calon guru dalam hal bagaimana proses pengembangan, implementasi dan evaluasi kurikulum (Nasir, 2013:202).

Tabel 6. Menunjukkan Sikap Positif dan Antusias

\begin{tabular}{llll}
\hline No & \multicolumn{1}{c}{ Pernyataan } & \multicolumn{2}{c}{ Kategori } \\
& & Ya $(\%)$ & \multicolumn{1}{c}{ Tidak $(\%)$} \\
\hline 1. & Kerja keras dan semangat dalam belajar & 62.5 & 37.5 \\
2. & Mengerjakan tugas tanpa bosan & 50 & 50 \\
3. & Menyelesaikan banyak hal meski ada kesulitan & 62.5 & 37.5 \\
4. & Inisiasi interaksi saat dibutuhkan & 37.5 & 62.5 \\
5. & Secara intrinsik termotivasi untuk sukses & 75 & 25 \\
6. & Tidak merengek atau terlalu mengeluh & 62.5 & 37.5 \\
\hline
\end{tabular}




\begin{tabular}{llll}
\hline 7. & Menunjukkan bangga dengan pekerjaannya & 75 & 25 \\
8. & menunjukkan ketertarikan pada diskusi / isu kelas & 62.5 & 37.5 \\
\hline
\end{tabular}

Tabel 6. menunjukkan sikap positif dan antusias dalam menjalankan kuliah, mahasiswa menunjukkan mereka semangat dan termotivasi untuk belajar secara umum diatas $50 \%$. Namun hanya $37,5 \%$ mahasiswa melakukan inisiasi interaksi saat dibutuhkan saja ini berarti mahasiswa pasif dalam interaksi kuliah sehingga pola komunikasi antara dosen dengan mahasiswa perlu ditingkatkan. Mahasiswa berkomunkasi tidak hanya pada saat kontrak kuliah namun komunikasi yang dibangun lebih intens lagi misalnya konsultasi selama dan proses kuliah.

\section{Profil Lulusan}

Pendidik Pendidikan Agama Islam (PAI) pada lembaga sekolah/madrasah dan luar sekolah yang memiliki kemampuan profesional, berdaya saing serta mampu merespon perkembangan zaman.

\section{E. Capaian Pembelajaran}

Capaian pembelajaran dari hasil penelitian ini berada pada domain sikap, pengetahuan, keterampilan umum dan keterampilan khusus yang tercantum pada tabel 7 sebagai berikut:

Tabel 7. Capaian Pembelajaran Jurusan Pendidikan Agama Islam (PAI)

\begin{tabular}{l}
\hline Capaian Pembelajaran \\
\hline 1. Bertakwa kepada Tuhan Yang Maha Esa dan mampu \\
menunjukkan sikap religius sebagai muslim, \\
mukmin, dan muhsin. \\
2. Toleran, Moderat, dan menjunjung tinggi nilai \\
kemanusiaan dalam menjalankan tugas berdasarkan \\
agama, moral, dan etika. \\
3. Berkontribusi dalam peningkatan mutu kehidupan \\
bermasyarakat, berbangsa, bernegara, dan kemajuan \\
peradaban berdasarkan Pancasila. \\
4. Berperan sebagai warga negara yang bangga dan \\
cinta tanah air, memiliki nasionalisme serta rasa \\
tanggungjawab pada negara dan bangsa. \\
5. Menghargai keanekaragaman budaya, pandangan, \\
agama, dan kepercayaan, serta pendapat atau temuan \\
orisinal orang lain. \\
6. Bekerja sama dan memiliki kepekaan sosial serta \\
kepedulian terhadap masyarakat dan lingkungan. \\
7. Taat hukum dan disiplin dalam kehidupan \\
bermasyarakat dan bernegara. \\
8. Menginternalisasi nilai, norma, dan etika akademik. \\
9. Menunjukkan sikap bertanggungjawab atas \\
pekerjaan di bidang keahliannya secara mandiri. \\
10. Menginternalisasi semangat kemandirian, kejuangan, \\
dan kewirausahaan.
\end{tabular}




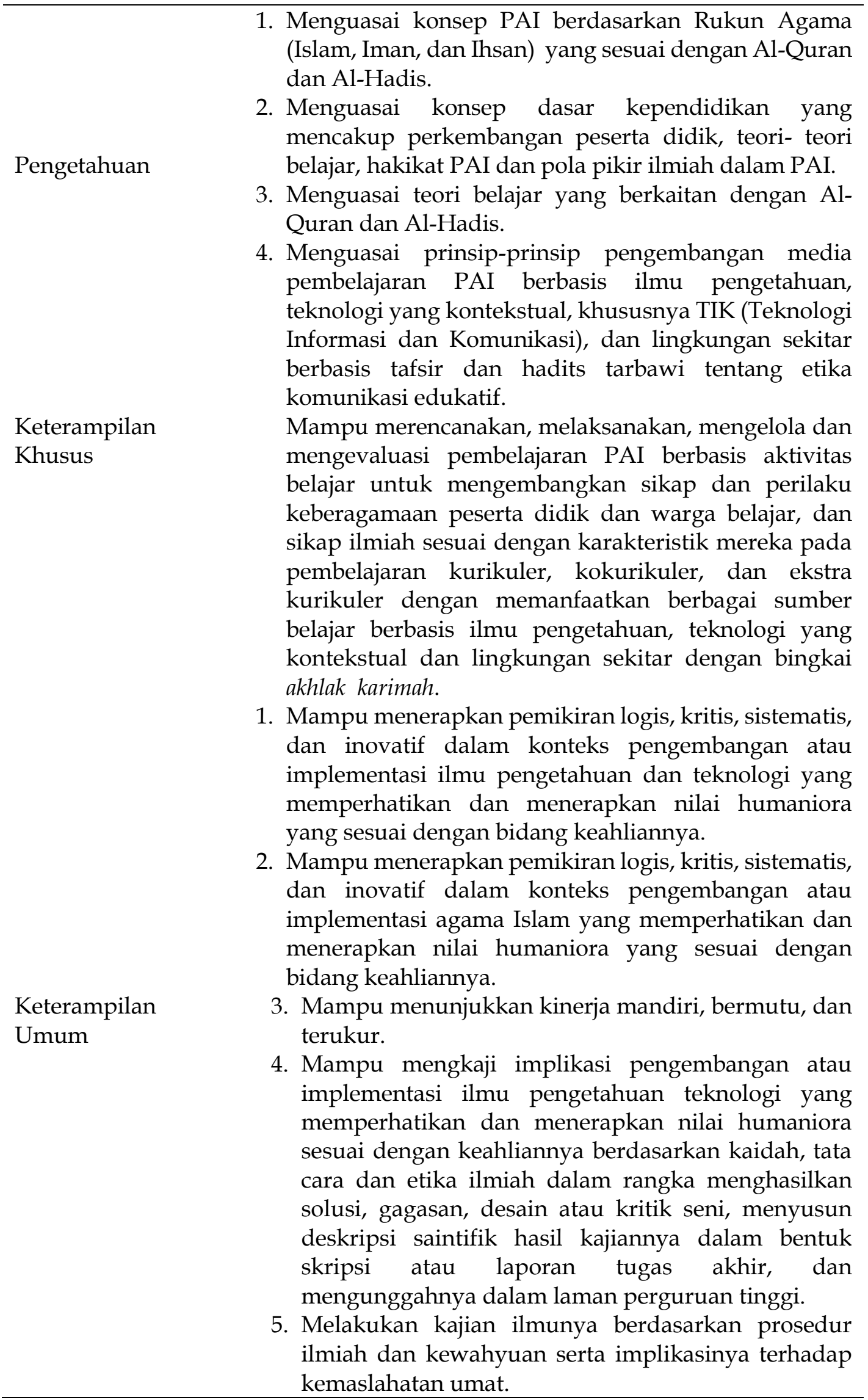




\section{Kompetensi Utama Lulusan}

a. Mampu menguasai konsep PAI berdasarkan rukun Agama (Islam, Iman dan Ihsan) yang sesuai dengan al-Quran dan al-Hadis.

b. Mampu menguasai konsep dasar kependidikan yang mencakup perkembangan peserta didik, teori-teori belajar, hakikat PAI dan pola pikir ilmiah dalam PAI.

c. Menguasai teori belajar yang berkaitan dengan al-Quran dan al-Hadis.

d. Mampu menguasai prinsip-prinsip pengembangan media pembelajaran PAI berbasis ilmu pengetahuan, teknologi yang kontekstual, khususnya TIK (Teknologi Informasi dan Komunikasi), dan lingkungan sekitar berbasis tafsir dan hadis tarbawi tentang etika komunikasi eduaktif.

e. Mampu merencanakan, melaksanakan, mengelola dan mengevaluasi pembelajaran PAI berbasis aktivitas belajar untuk mengembangkan sikap dan perilaku keberagamaan peserta didik dan warga belajar, dan sikap ilmiah sesuai dengan karakteristik mereka pada pembelajaran kurikuler, ko kurikuler dan ekstra kurikuler dengan memanfaatkan berbagai sumber belajar berbasis ilmu pengetahuan, teknologi yang kontekstual dan lingkungan sekitar dengan bingkai akhlak karimah.

Kompetensi Pendukung

a. Mampu mengoperasikan perangkat teknologi informasi dan komunikasi untuk peningkatan produktivitas kinerja seorang guru PAI.

b. Mampu menggunakan metode kuantitatif yang tepat untuk menganalisis dan mensintesis data dan informasi yang relevan bagi mutu pembelajaran PAI di kelas.

c. Mampu berkomunikasi dengan baik terhadap para peserta didik, sesama pendidik, dan masyarakat.

d. Mampu menyajikan gagasan dan atau laporan kinerja guru, baik secara tertulis maupun lisan.

\section{Kompetensi lainnya}

a. Mampu menerapkan pemikiran logis, kritis, sistematis, dan inovatif dalam konteks pengembangan atau implementasi ilmu pengetahuan dan teknologi yang memperhatikan dan menerapkan nilai humaniora yang sesuai dengan bidang keahliannya.

b. Mampu menerapkan pemikiran logis, kritis, sistematis, dan inovatif dalam konteks pengembangan atau implementasi agama Islam yang memperhatikan dan menerapkan nilai humaniora yang sesuai dengan bidang keahliannya.

c. Mampu menunjukkan kinerja mandiri, bermutu, dan terukur.

d. Mampu mengkaji implikasi pengembangan atau implementasi ilmu pengetahuaan teknologi yang memperhatikan dan menerapkan nilai humaniora sesuai dengan keahliannya berdasarkan kaidah, tata cara dan etika ilmiah dalam rangka menghasilkan solusi, gagasan, desain atau kritik seni, menyusun deskripsi saintifik hasil kajiannya dalam bentuk skripsi atau laporan tugas akhir, dan mengunggahnya dalam laman perguruan tinggi.

e. Mampu melakukan kajian ilmunya berdasarkan prosedur ilmiah dan kewahyuan serta implikasinya terhadap kemaslahatan umat 


\section{SIMPULAN}

Kesiapan mahasiswa menjadi guru PAI, mengevaluasi kurikulum yang telah dilaksanakan sehingga diharapkan mahasiswa calon guru siap untuk menjadi guru. Indikator yang diamati untuk mengukur kesiapan mahasiswa menjadi guru yaitu Tingkat kepercayaan calon guru PAI berada pada kategori tinggi dengan motivasi dan akktivitas pembelajaran calon guru PAI pada kategori sedang. $50 \%$ lebih mahasiswa menunjukkan profesionalisme dan menunjukkan sikap positif dan antusias dalam melaksanakan kuliah pada jurusan PAI. Keprofesionalan ini diamati dari hasil lembar observasi dosen terhadap mahasiswa yang sedang mengikuti kuliah microteaching, mahasiswa memiliki kemampuan menyampaikan materi dengan baik tetapi perlu ditingkatkan dalam hal kemampuan memahami dan mengerti dengan baik hadist dan kemampuan bahasa arab.

\section{REFERENSI}

Carr, M. (2001). Asesmen in early childhood settings: Learning stories. London: PaulChapman.

Irawan, P. (2010). Hubungan Persepsi terhadap Kompetensi Guru dengan Motivasi Berprestasi Siswa Kelas VII SMP Negeri 2 Tirto (Doctoral dissertation, UNDIP).

Ismail, M. I. (2010). Kinerja dan kompetensi guru dalam pembelajaran. Lentera Pendidikan: Jurnal Ilmu Tarbiyah dan Keguruan, 13(1), 44-63.

(LPMP), L. P. M. P., 2011. Hasil Uji Kompetensi Guru, Bandung: LPMP.

KKNI, T. P., 2016. Kurikulum Jurusan Pendidikan Agama Islam Mengacu pada KKNI dan SNPT. 1 ed. Bandung: Jurusan PAI FTK UIN Sunan Gunung Djati.

Nasir, M. (2013). Profesionalisme Guru Agama Islam: Sebuah Upaya Peningkatan Mutu Melalui LPTK. Dinamika Ilmu, 13(2).

Sagala, S. (2006). Administrasi Pendidikan Kontemporer. Bandung, Al-fabeta

Sanjaya, W. (2006). Strategi pembelajaran. Berorientasi Standar Pendidikan. Jakarta. Kencana Penada Media.

Suhadi, E., Mujahidin, E., Bahruddin, E., \& Tafsir, A. (2014). Pengembangan Motivasi dan Kompetensi Guru dalam Peningkatan Mutu Pembelajaran di Madrasah. Ta'dibuna: Jurnal Pendidikan Islam, 3(1), 42-60.

Sugilar, H., 2017. Implementasi Model Perkuliahan Assesment for Learning dalam Meningkatkan Kemampuan Pembuktian pada Mahasiswa Pendidikan Matematika. Jurnal Perspektif, 1(1), p. 11.

Sutiarso, S., 2017. Teachers' Belief dalam Pembelajaran Matematika dan Faktor-Faktor yang Mempengaruhinya. JPPM Vol. 10 No. 2 (2017), 10(2), pp. 1-7. 